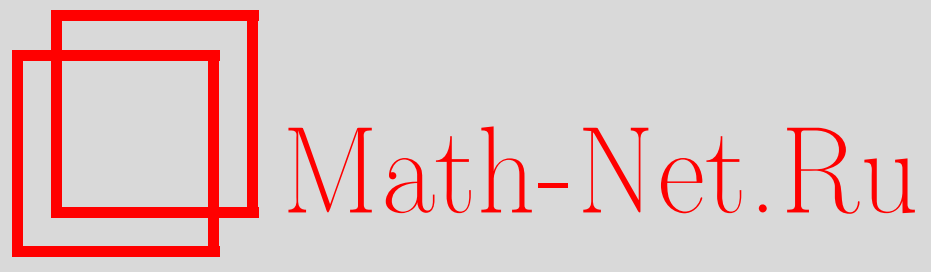

Исправление к статье, Матем. сб., 2020, том 211, номер 8, 158

DOI: https://doi.org/10.4213/sm9471

Использование Общероссийского математического портала Math-Net.Ru подразумевает, что вы прочитали и согласны с пользовательским соглашением http://www.mathnet.ru/rus/agreement

Параметры загрузки:

IP: 3.85 .73 .92

26 апреля 2023 г., 17:20:35

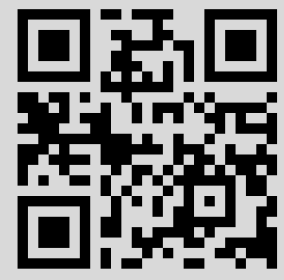




\section{ИСПРАВЛЕНИЕ К СТАТЬЕ}

В статье Д. П. Ильютко, Е. А. Севостьянова "О граничном поведении открытых дискретных отображений на римановых многообразиях. II" ("Математический сборник", 2020, т. 211, № 4, с. 63-111) по техническим причинам в названии была пропущена римская цифра II.

Правильным названием указанной статьи в дальнейшем необходимо считать "О граничном поведении открытых дискретных отображений на римановых многообразиях. II". 